\title{
Community Perspectives Concerning Discipline to Wards Large-scale Social Restrictions (LSSR) and Social Distancing when Covid-19
}

\author{
$1^{\text {st }}$ Siti Aminah $^{1}, 2^{\text {nd }}$ Dewi Khairani ${ }^{2}, 3^{\text {rd }}$ JM. Muslimin ${ }^{3}, 4^{\text {th }}$ Asep Saepudin Jahar ${ }^{4}$, \\ $5^{\text {th }}$ Arif Zamhari ${ }^{5}, 6^{\text {th }}$ Kamarusdiana $^{6}$ \\ \{siti.aminah17@mhs.uinjk.ac.id ${ }^{1}$,dewi.khairani@uinjkt.ac.id², muslimin@uinjkt.ac.id ${ }^{3}$, \\ asepjahar@uinjkt.ac.id ${ }^{4}$, arif.zamhari@uinjkt.ac.id ${ }^{5}$, kamarusdiana@uinjkt.ac.id $\left.{ }^{6}\right\}$ \\ Syarif Hidayatullah State Islamic University of Jakarta, Indonesia ${ }^{1,2,3,4,5,6}$
}

\begin{abstract}
The perspective of society regarding PSBB and Social Distancing is of course vary. The Covid-19 pandemic is not only happening in Indonesia but throughout the world. This PSBB and Social Distancing policy is an effort to break the chain of spreading the Covid-19 pandemic. The implementation of PSBB and Social Distancing is based on government regulations in articles 59 and 60 of Law Number 6 of 2018 concerning health quarantine, with rules and procedures for prevention. The purpose of this study is to determine the perspective of the community on discipline regarding the PSBB and social distancing regulations that have been set by the government. The method used in this study using qualitative methods with data collection techniques through observation and interviews. Based on the research results, It can be concluded that the community's self-awareness is still minimal because there are still many people who carry out activities outside the home to fulfill their needs, such as working by still following health protocols, but some people consider this policy trivial. Even though the government has imposed a new normal, it does not mean that this pandemic is over but it must be more concerned and still apply health protocols.
\end{abstract}

Keywords: LSSR, Social Distancing, Self-Awareness, Covid-19

\section{Introduction}

The world, including Indonesia, is facing a very terrible and terrible epidemic, namely a pandemicCorona Virus Disease 2019 or often called Covid-19. Currently, on August 10, 2020, 127,083 cases of COVID have been recorded in Indonesia. This virus was first discovered in Wuhan City, China at the end of December 2019. Coronavirus is part of a disease virus class that causes diseases that occur in humans and animals. Coronaviruses are pathogenic microorganisms that infect living things, coronaviruses consist of DNA and RNA. Also, the coronavirus is transmitted very quickly and spreads to all parts of the world. According to WHO, people who have weak COVID-19 immunity can have fatal consequences and result in death if they do not get proper medical treatment in the form of complete isolation and quarantine.

Around the world and especially in areas in Indonesia, many people have been positively affected by Covid-19, even increasing every day. Therefore preventive steps were taken in the form of large-scale social distancing and social distancing both on a full and limited scale. 
This policy has been forced to be taken by many countries as a bitter choice to minimize and suppress the number of Covid-19 spread which continues to increase from time to time because until now there has not been a vaccine to deal with this outbreak.

People in Indonesia must apply disciplined behavior in the PSBB (Large-Scale Social Restrictions) and Social Distancing policies that have been appealed to by the government because the implementation of this policy is a further effort to prevent the outbreak of the COVID pandemic19. And it is believed to be the most effective way to reduce the rate of transmission of the Corona Virus or COVID 19 pandemic.

\section{Literature Review}

In the journal entitled "Implementation of Large-Scale Social Restrictions, A Public Policy in Handling the Covid-19 Pandemic" by Ahmad Fauzi and Widyaiswara, it can be concluded that the understanding related to the legal basis and policy implementation is in the unity of perceptions, views, so there is still bias in the stages. implementation as well The implementation of the PSBB policy for the DKI Jakarta area and the West Answer can be declared a success, this can be seen from several things, including the readiness of public officials in handling the spread of the epidemic, supporting facilities, availability of costs, coordination with the parties involved and sanctions given to policy violators, The conditions in the field that can be observed related to the handling of Covid-19 are a unit of command, public officials, in this case, the Governor immediately came down to monitor policies and there has been a decrease in the Covid-19 case. As well as supporting facilities to deal with the Covid-19 pandemic such as Personal Protective Equipment (PPE), ventilators and masks are still limited. But for DKI and West Java a solution can be found[1].

In a journal entitled "The Effectiveness of Large-Scale Social Restrictions in Bekasi City in Overcoming Covid-19 with a Model Susceptible-Infected-Recovered (SIR) "essay Rahmadya Trias and Herlawati, it can be concluded that the simulation results with the SIR Model show a reduction in COVID-19 cases in Bekasi City. This shows the good effects of the implementation of PSBB in the city, as well as the effectiveness in other areas that have implemented PSBB as a comparison, for example, the City of DKI Jakarta. Of course, other matters still need to be studied accompanying the PSBB policy, such as economic, social, and cultural issues. However, it is necessary to maintain strict supervision, especially when starting to switch from PSBB to the policy under normal conditions[2].

In the journal entitled "The Effect of Physical Distancing and Social Distancing on Health in a Linguistic Approach" by Arief Kresna and Juni Akhyar, it can be concluded that the Indonesian government is the right policy to reduce the impact of the spread of the Covid-19 virus infection in Indonesia. The policy chosen has also been by WHO's appeal regarding physical and social distancing. We can find this in public places, where we can see the physical distancing symbol that indicates the distance between a person and another person, such as those at bus stops, train stations, supermarkets, until public transportation has started using numbers or distance marks to maintain limit visitors to avoid physical contact with other visitors.

Based on the explanation above, it shows that the physical distancing and social distancing policies have a significant effect on public health, where the physical distancing and social distancing policies adopted by the government can inhibit the spread of the Covid19 virus infection among the community. By implementing health protocols and efforts that 
need to be considered by the wider community to always maintain cleanliness and implement a healthy lifestyle so that people avoid the danger of transmission and the effects of health problems from the transmission of the Covid-19 virus[3].

In the journal entitled "The Influence of Social Distancing Policies on the Covid-19 Outbreak on Vulnerable Groups in Indonesia "by Anung Ahadi Pradana, Casman, and Nur'aini it can be concluded that in a pandemic phase that requires the implementation of social distancing for society, vulnerable groups consisting of children, pregnant women and the elderly are among the groups that experience the worst impacts. Health workers are required to prioritize assessments of vulnerable groups with preparation in terms of understanding related to COVID-19, how to prevent it, obstacles that may occur in implementing prevention efforts, and what modifications can vulnerable groups make to support social distancing efforts. The need for the welfare of vulnerable groups to be considered due to the low access to social and health services that can be reached by this group. Important things to the attention of health workers during the COVID-19 pandemic include: Continuing primary prevention through routine screening and isolation to reduce the spread of disease, using internet-based Counseling, Information and Education (IEC) techniques for the community to reduce dependency community in primary and secondary health services, creating programs to protect vulnerable groups from infections that occur, and ensuring fast response services and supporting tools in hospitals, especially services for the elderly[4].

In the journal entitled "Raising the Awareness of the Indonesian people to Break the Chain of Spread of the Covid-19 Outbreak" by Sinar Rizki A, et al, it can be concluded that SARS-COV2 is also included in the scope of the coronavirus class which is also the same cause as the SARS health case that arises. in 2003, this disease can cause respiratory problems and inflammation of the lungs. The disease is caused by SARS-Cov-2 infection and can be transmitted by coughing droplets from person to person. Symptoms that arise vary, including the usual flu symptoms (fever, cough, headache, runny nose, sore throat, muscle aches) to serious complications (sepsis or pneumonia.) We must be careful with the Covid-19 virus. and we can reduce the transmission of the COVID-19 virus by 1) Wash your hands with hand soap and running water. Do not touch the mouth, nose, eyes, and facial areas before washing hands thoroughly. Use a hand sanitizer if there is no water. (2) don't forget to wear a mask when in public places. Apply cough etiquette when not wearing a mask by covering your nose and mouth using your arms, or you can also use a tissue, and also don't forget to throw the tissue in the trash. (3) Perform physical distancing, namely by maintaining distance and also avoiding crowds. When in a crowd, don't forget to leave 1-meter distance from the people in the crowd. (4) Avoid direct contact, such as shaking hands, hugging, because it can cause infection with the virus. (5) Maintain cleanliness and environmental health. (6) Maintain a healthy body by eating nutritious foods and also exercising regularly, (7) Doing positive activities, doing activities that you like to avoid stress. (8) Pray and draw closer to God. (9) Go to the hospital if you feel the symptoms of the Covid19 virus and also do self-isolation[5].

\section{Theoretical Basis}

\subsection{Public}

The term community comes from the Arabic word "syaraka" which means to participate, participate, or "musyaraka" which means to hang out with one another. The term society is 
also known in English, namely, society, which was previously derived from the Latin socius, which means "friend"[6]. According to John Lewis Gillin and John Phillip Ghillie, society is the largest group of people who share the same customs, attitudes, and feelings of unity. The society includes smaller groupings[7].

According to Ralph Linton, society is a group of people who have been working together for a long time, so that they can organize themselves as a social unit with certain boundaries.24 This definition shows that there are conditions that are called society, namely the existence of life experiences. together for quite a long time and there is cooperation among group members, have thoughts or feelings of being part of one group unit.

The experience of living together gives rise to cooperation, adaptation to the organization, and patterns of behavior of members. The time factor plays an important role because after living together for a long time, there is a process of adaptation to organizational behavior and group awareness[8]. Meanwhile, according to the National Education System Law Number 20 of 2003 Article 1 Paragraph 27, the community is a group of nongovernmental Indonesian citizens who have concerns and roles in the field of education[9].

\subsection{Large-Scale Social Restrictions}

Large-Scale Social Restrictions (PSBB) are restrictions on certain activities of residents in an area suspected of being infected with a disease and/or contamination in such a way as to prevent the possibility of spreading disease or contamination. If we take a closer look at the definition of PSBB, which is stated in the general provisions, it has the same principles as physical distancing, namely the limitation of community activities. Territorial quarantine in general terms is a restriction on the population in an area, including the area of entrance and its contents, who are suspected of being infected with the disease and/or contaminated in such a way as to prevent the possibility of spreading disease or contamination. Entrance referred to here has the meaning as a place for the entry and exit of all types of vehicles, people, and / or goods, either in the form of ports, airports, as well as state land border crossings. The regional quarantine mechanism is regulated in Article 54 and Article 55 in Law no. 6 of 2018[10].

\subsection{Social Distancing}

Social Distancing or it can be interpreted as social distancing restrictions when referring to an article in the Public Health Department (Yusup et al., 2020), it is explained that social distancing means creating distance between oneself and others to prevent transmission of certain diseases.

In Indonesia, the term social restrictions have been regulated in Articles 59 and 60 of Law Number 6 of 2018 concerning Health Quarantine (Setiawan, 2020). This rule also explains the difference in meaning between lockdown and social distancing. According to the law, regional quarantine (lockdown) is a restriction on the population in an area including the area of entrance and its contents that are suspected of being infected with a disease and/or being contaminated in such a way as to prevent the possibility of spreading a disease or being contaminated. Meanwhile, social distancing is the limitation of certain activities of residents in an area that is suspected of being infected with a disease and / or contamination in such away.

In the application of social distancing, a person is not allowed to shake hands and always pay attention and maintain a distance of at least 1-2 meters when interacting with other people, especially with someone who is sick or at high risk of suffering from Covid-19. There are several examples of the application of social distancing that is commonly done, namely 
working from home, studying at home for students and students, postponing meetings or events that are attended by many people, not visiting people who are sick but simply by telephone call or teleconference.as to prevent the possibility of spreading the disease or contamination[3].

\subsection{Concept of Self-Awareness}

Consciousness has the same meaning as introspection (awareness). Consciousness is also defined as a condition in which an individual has full control over internal and external stimuli [11]. Joseph Murphy in his book Amos Neolaka defines consciousness, which is awake or aware of behavior where the conscious mind regulates reason and makes choices about what is desired, for example, good and bad, beautiful and ugly, and so on[12]. According to Hurssel in his book Amos Neolaka, Consciousness is the conscious mind (knowledge) that regulates reason. This thought inspires the soul to make choices of good and bad, beautiful and bad, and others[12].

Self-awareness is the basis of emotional intelligence. The ability to monitor emotions over time is essential for psychological insight and self-understanding. Someone who has emotional intelligence will try to be aware of his emotions when they control him. But this self-awareness does not mean that a person is carried away in the flow of his emotions so that the mood takes over him completely. Conversely, self-awareness is a state when a person can become aware of the emotions that are coming on his mind as a result of the problems at hand so that he can master them later. People who have more confidence in their emotions are likened to reliable pilots for their lives. Because he has a higher sensitivity to their true emotions[13].

Binswanger and Boss describe self-awareness as one of the unique and fundamental characteristics of humans, which distinguishes humans from other creatures. In short, in their view, self-awareness is the capacity that enables humans to live as a whole and full persons. They will reject the term personality if the term refers to a set of traits or traits that remain in humans. They developed the concept of being-in-the-world namely; the physical world or the biological world (Umlet), the human world, or the social world (Mitwelt), the world itself including human needs (Eigenwelt). They believe that each individual's personality is unique and can be distinguished by the way he exists in or relates to the three levels of the world. What is meant by "the world" according to Husserl's view, actually not the world as understood or interpreted by scientific theories? A world that is directly and without an intermediary, experienced by every individual in everyday life. Nothing but a pure symptom or phenomenon. This is the world that humans live, live, or experience.

From the various opinions above, it can be concluded that self-awareness (selfconsciousness) is one of the unique and fundamental characteristics of humans, where humans have an-in-the-world consciousness (umwelt, mitwelt, eigenwelt). Also awareness of beingoutside the world (becoming = imprisonment), namely freedom that cannot be separated from responsibility.

Umweltcan is understood as a "ser world" (natural world) if the biological world is equated with the environment (environment) that is related to biological needs; urges, instincts. It can be defined as the world of natural laws and scientific cycles, the world of sleeping and waking, birth, and death. Mitwelt means human relations with other humans, in humans, there is communication that involves meaning, the meaning of others is partly determined by relationships with one another, the essence of relationship is that the encounter of two persons is changed. The relationship always involves mutual awareness, and this 
always happens in an encounter. Meanwhile, eigenwelt means self-awareness, which is related to oneself and the unique way it is present in humans.

\section{Research Methods}

This research was conducted using qualitative methods. Qualitative methods are often called naturalistic research methods because the research is carried out in natural conditions (natural setting)[14].

In qualitative research, researchers are required to be able to extract data based on what the data sources say, feel, and do. In qualitative research, the researcher is not what the researcher thinks should be but is based on what is happening in the field, experienced felt, and thought by the data source. (Moleong 2005) This qualitative approach was chosen because researchers wanted to know the meaning understood by the subjects in this study. The qualitative approach always tries to understand the meaning of the subject under study, where the researcher observes and makes intensive interaction or communication with the subject under study to be able to understand and develop categories, patterns, and analysis of social processes that occur in society.

The data collection technique in this study was carried out by observation in the form of direct and online interviews, which amounted to 3 informants. By asking about perspectives about discipline on PSBB (Large-Scale Social Restrictions) and Social Distancing during the Covid-19 pandemic.

The descriptive data analysis model used in this research, described in Fig. 1 below.

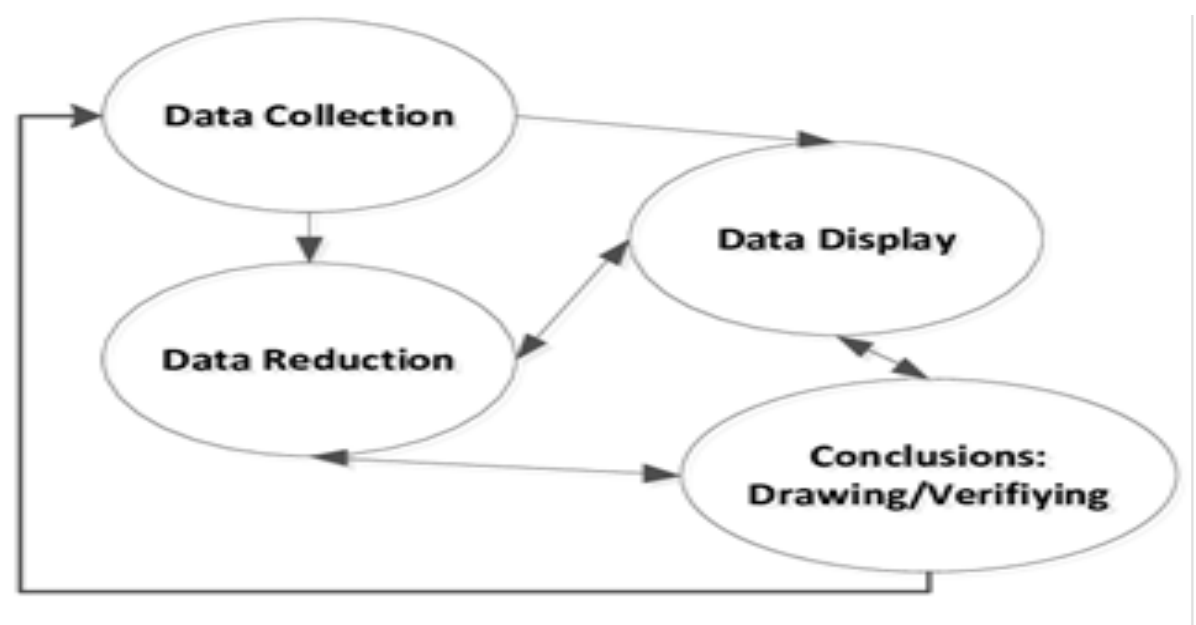

Fig. 1. Qualitative descriptive data analysis model of Miles dan Huberman[15]. 


\section{Result and Discussions}

From the results of research that has been conducted by researchers when conducting interviews, that the steps of the community that have been carried out in the disciplinary policies of PSBB and Social Distancing around the area where they live, such as in RW areas that implement a lockdown system, namely the entry and exit point for people to the RW area through one door (one aisle) and the other aisle is closed. Also, other steps are being taken towards this policy, namely continuing to carry out positive activities and activities in the home. The sanctions have given by the government for violating these policies according to article 93 and article 9 of Law No.6 of 2018 regarding health quarantine, one year sanction, and a fine of 100 million rupiahs, and in Article 27 concerning violations of the PSBB, sanctions will be imposed following the laws and regulations starting from minor crimes and if repeated, they can be more severe. Then the sanctions are given to each region vary, such as in the form of physical sports such as push-ups, running, etc. "I broke the PSBB rules" and then swept along the street.

The PSBB and Social Distancing policies carried out by the government during this pandemic are one of the best solutions in overcoming the spread of Covid-19, but with this policy, it is not entirely a good solution, surely every policy has pros and cons, the cons of this policy are A new problem that will arise is that the economy will deteriorate, but still have to comply with the PSBB policy so that the spread of the virus can quickly end. With this pandemic, people initially experienced anxiety if they left the house because they were afraid of contracting Covid-19, but with this policy, people are required to think more critically and selectively so that the anxiety felt by the community is slightly less than before the existence of this policy, especially now that it is already in place. in new-normal times.

The negative impact that is caused if the community violates the PSBB and social distancing policies is to cut off the economic income of the Indonesian people because with this pandemic many workers have been laid off and many business people close their businesses, the biggest impact that will occur is the wider area of distribution and also people.

The number of people who are positive for COVID-19 is increasing. While the positive impact of this policy is by carrying out activities and activities at home so that it can prevent the entry of new cases or slow down and prevent the transmission of the Covid-19 virus in the local community, carrying out activities at home can also help ease the task. the doctors and nurses who treat COVID-19 patients at the hospital.

The right solution for people who still violate this policy is to give a warning to people who still violate it and if necessary, they must be subject to heavy sanctions. Even though they are required to leave the house for important activities, people are still obliged to wear masks and comply with health protocols.

\section{Conclusion}

Based on the analysis and discussion of the research entitled "Public Perspectives Regarding Discipline Against PSBB (Large-Scale Social Restrictions) and Social Distancing Policies During COVID - 19" it can be concluded that All over the world and especially in areas in Indonesia, there are already many people who are positively affected by COVID - 19 every day, because of that preventive steps are taken in the form of social distancing and social distancing both on a full and limited scale. The PSBB (Large-Scale Social Restriction) 
issued by the Ministry of Health is a countermeasure and at the same time prevents the spread of Covid-19 which is increasingly widespread in Indonesia. Meanwhile, social distancing is restrictive action by keeping a distance of at least two meters from other people and avoiding crowds to prevent disease transmission.

The steps given by the government in this PSBB and Social Distancing policy are providing health protocol directions, namely by urging the public to keep their distance and keep wearing masks, wash their hands, etc. Besides that, the government also implements this policy so that people stay at home and carry out activities at home. as well as work from home, distance education, and others. The government also provides sanctions for violating the policy in the form of fines, minor criminal sanctions and if repeated, they can be heavier.

The PSBB and social distancing policies can be solutions that can overcome the spread of COVID-19 which is increasing every day in Indonesia, but this policy, it is not entirely a good policy, there are pros and cons in every policy, the cons are that with this policy there are new problems. what will arise is that the economy will deteriorate, but still have to comply with the PSBB policy so that the spread of the virus can quickly end. 


\section{References}

[1] W. Ahmad Fauzi, "Implementasi Pembatasan Sosial Berskala Besar, Sebuah Kebijakan Publik Dalam Penangan Pandemi Covid-19,” J. Ilmu Adm. Negara, vol. 16, pp. 174-178, 2020.

[2] R. T. Handayanto and H. Herlawati, "Efektifitas Pembatasan Sosial Berskala Besar (PSBB) di Kota Bekasi Dalam Mengatasi COVID-19 dengan Model Susceptible-Infected-Recovered (SIR)," $J$. Kaji. Ilm., vol. 20, no. 2, pp. 119-124, 2020, doi: 10.31599/jki.v20i2.119.

[3] Arief Kresna dan Juni Ahyar, "Pengaruh Physical Distancing Dan Social Distancing Terhadap Kesehatan Dalam Pendekatan Linguistik,"Syntax Transform., vol. 1, pp. 14-19, 2020.

[4] A. A. Pradana, Casman, and Nur'aini, "Pengaruh Kebijakan Social Distancing Pada Wabah Covid-19 Terhadap Kelompok Rentan Di Indonesia," J. Kebijak. Kesehat. Indones., vol. 9, no. 1, pp. 34-39, 2020.

[5] D. Sinar Rizky A, Anita Trisiana, Farid Ajrur R, "Menumbuhkan Kesadaran Masyarakat Indonesia Untuk Memutus Rantai Penyebaran Wabah Covid-19," J. Ilm. Kaji. Pendidik. Kewarganegaraaan, pp. 51-62, 2020, doi: 10.1017/CBO9781107415324.004.

[6] Koentjaraningrat, "Pengantar Ilmu Antropologi". Jakarta: Rineka Cipta, 2009.

[7] John Lewis Gillin dan John Philip Ghillin, An Intriduction to Sociology. Macmillan: University oF Michigan, 1942.

[8] Basrowi, Pengantar Sosiologi. Bogor: Ghalia Indonesia, 2005.

[9] Undang-undang Republik Indonesia Nomor 20 Tahun 2003. Yogyakarta: Pustaka Pelajar, 2009.

[10] M. I. Lestari, "Signifikansi Pengaruh Sentimen Pemberlakuan PSBB Terhadap Aspek Ekonomi: Pengaruh Pada Nilai Tukar Rupiah dan Stock Return,” J. Bina Akuntasi, vol. 7, p. 227, 2020.

[11] Imam Malik, Pengantar Psikologi Umum. Yogyakarta: Teras, 2005.

[12] Amos Neolaka, Kesadaran Lingkungan. Jakarta: Rineka Cipta, 2008.

[13] Daniel Goleman, Emotional Intelligence Why IT Can Matter More Than IQ. New York: Bantam Books, 1996.

[14] Sugiyono, Penelitian Kualitatif. 2009.

[15] M. A. Miles, "Miles and Huberman (1994)- Chapter 4.pdf," in Qualitative Data Analysis: An Expanded Sourcebook, 1994. 